\title{
New Crocodyliform specimens from Recôncavo-Tucano Basin (Early Cretaceous) of Bahia, Brazil
}

\author{
RAFAEL G. DE SOUZA ${ }^{1}$ and DIOGENES A. CAMPOS ${ }^{2}$
}

\author{
${ }^{1}$ Laboratório de Sistemática e Tafonomia de Vertebrados Fósseis, Setor de Paleovertebrados, \\ Departamento de Geologia e Paleontologia, Museu Nacional, Universidade Federal do Rio de \\ Janeiro, Quinta da Boa Vista, s/n, São Cristóvão, 20940-040 Rio de Janeiro, RJ, Brazil \\ ${ }^{2}$ Museu de Ciências da Terra - CPRM, Av. Pasteur, 404, 22290-255 Rio de Janeiro, RJ, Brazil \\ Manuscript received on May 19, 2017; accepted for publication on October 23, 2017
}

\begin{abstract}
How to cite: SOUZA RG AND CAMPOS DA. 2019. New Crocodyliform specimens from Recôncavo-Tucano Basin (Early Cretaceous) of Bahia, Brazil. An Acad Bras Cienc 91: e20170382. DOI 10.1590/0001-3765201720170382.

Abstract: In 1940, L.I. Price and A. Oliveira recovered four crocodyliform specimens from the Early Cretaceous Bahia Supergroup (Recôncavo-Tucano Basin). In the present work, we describe four different fossil specimens: an osteoderm, a fibula, a tibia, and some autopodial bones. No further identification besides Mesoeucrocodylia was made due to their fragmentary nature and the reduced number of recognized synapomorphies for more inclusive clades. With exception of the fibula, all other specimens have at least one particular feature, which with new specimens could represent new species. The new specimens described here increase the known diversity of Early Cretaceous crocodyliforms from Brazil. This work highlights the great fossiliferous potential of Recôncavo-Tucano Basin with regard to crocodyliform remains.
\end{abstract}

Key words: Crocodyliforms, Early Cretaceous, Recôncavo Basin, Tucano Basin.

\section{INTRODUCTION}

The first Brazilian Crocodyliformes species described come from the Early Cretaceous rocks of Recôncavo Basin, State of Bahia (Marsh 1869, Riff et al. 2012). Those materials were collected by Allport and reported in 1860. For 1864-1865, complementary materials were collected by Thayer Expedition -led by L. Agassiz- with the effective participation in the field of C. F. Hartt (Allport 1860, Mawson and Woodward 1907, Freitas 2002). Based on the two tooth morphotypes described by

Correspondence to: Rafael Gomes de Souza

E-mail: rafelsouz@gmail.com

ORCid: http://orcid.org/0000-0003-2819-7776

* Contribution to the centenary of the Brazilian Academy of Sciences.
Allport (1860), Marsh (1869) proposed two new species Crocodylus hartti Marsh, 1869, at present is known as Sarcosuchus hartti (Marsh, 1869) proposed by Buffetaut and Taquet (1977), and Thoracosaurus bahiensis Marsh, 1869, considered as nomen dubium by Souza et al. (2015). Despite these promising early findings, all other noneusuchian crocodyliforms in Brazil were found outside of Bahia (e.g., Price 1945, 1955, Riff et al. 2012, Iori and Arruda-Campos 2016).

The present contribution describes some isolated postcranial fossil elements, which are collected by L.I. Price team during the Spring of 1940 in a field work in Recôncavo-Tucano Basins. The description of these materials and its phylogenetic relationships are provided. This brings 
Bahia basins back to the paleontological scenario, which its geological temporal time lapse and its fossil contents are not yet adequately explored.

\section{GEOLOGICAL SETTINGS}

The Cretaceous rocks are nested within the Recôncavo-Tucano-Jatobá aborted intracontinental rift (opened in Late Jurassic to Early Cretaceous during South Atlantic rifting), which is located in Northeast Brazil (State of Bahia; Figure 1a), being filled with non-marine sediments (Milani and Davison 1988, Maisey 2000, Costa et al. 2007, Silva et al. 2007). The Recôncavo Basin and both Tucano Sul and Central Sub-Basins are divided and delimited by the geological structures featured in Figure 1b (based in: Milani and Davison 1988, Bruhn 1999, Costa et al. 2007, Silva et al. 2007). However, only the Recôncavo Basin and Tucano Sul Sub-Basin are discussed here.

The Recôncavo Basin and Tucano Sul SubBasin are chronostratigraphically correlated groups (Costa et al. 2007, Silva et al. 2007): Santo Amaro, Ilhas, and Maçacará (Massacará, in the old style). Those three groups are usually recognized within the Early Cretaceous of the Supergroup Bahia (Lima et al. 1981, Gava et al. 1983), yet there is some discussion if Salvador Formation is exclusively from Recôncavo Basin (Lima et al. 1981, Gava et al. 1983) or not (Costa et al. 2007, Silva et al. 2007). However, as a result of different regional variations on the paleoenvironments, this correlation is not well understood based on differences in abundance and geographical distribution of those Formations, being the Recôncavo Basin more diverse than Tucano Sul Sub-Basin in terms of Formations diversity (e.g., Costa et al. 2007, Silva et al. 2007).

Regarding the paleoenvironment, the rocks within the Recôncavo Basin and Tucano Sul SubBasin are non-marine in its origins. The Formations paleoenvironment extends from the lacustrine system, during the Berriasian-Valanginian, to a fluvial system, during the Valanginian-Barremian. Therefore, this succession of paleoenvironment can be interpreted as a regressive system (Milani and Davison 1988, Bruhn 1999, Costa et al. 2007, Silva et al. 2007).

\section{MATERIALS AND METHODS}

\section{STUDIED AREA AND MATERIALS}

The four postcranial crocodyliform specimens, which were collected by L.I. Price and A. Oliveira, proceed from the following localities:

Tracupá Locality (Figure 1b, locality 1): locality previously recognized by Melo Junior and Oliveira (1939), Campos and Campos (1976a). L.I. Price and A. Oliveira informed that the material comes from Pé do Alto Hill. This specimen consists on a well-preserved osteoderm (MCT 1860-R).

Quererá Locality (Figure 1b, locality 2): locality previously recognized by Campos and Campos (1976a). L.I. Price and A. Oliveira informed that the material comes from Quererá River. This specimen consists on a fragmentary fibula (MCT 1859-R).

Queimada Grande Locality (Figure 1b, locality 3): locality was not previously recognized in the literature. No further information was given by L.I. Price and A. Oliveira. This specimen consists of three phalangeal bones, an ungueal, a radiale, and a distal end of a radius (MCT 1861-R).

Candeias Locality (Figure 1b, locality 4): locality previously recognized by Campos and Campos (1976b). L.I. Price and A. Oliveira informed that the material comes from the Pixuna River, and consists on an almost complete tibia (MCT 1862-R).

In September 1985, one of the authors (DAC) had the opportunity to carry out a brief survey in the surroundings of Tracupá and Pé do Alto (Municipality of Tucano, Bahia) together with Sylvie Wenz (Muséum National d'Histoire Naturelle, Paris), and Paulo Brito (Geological 

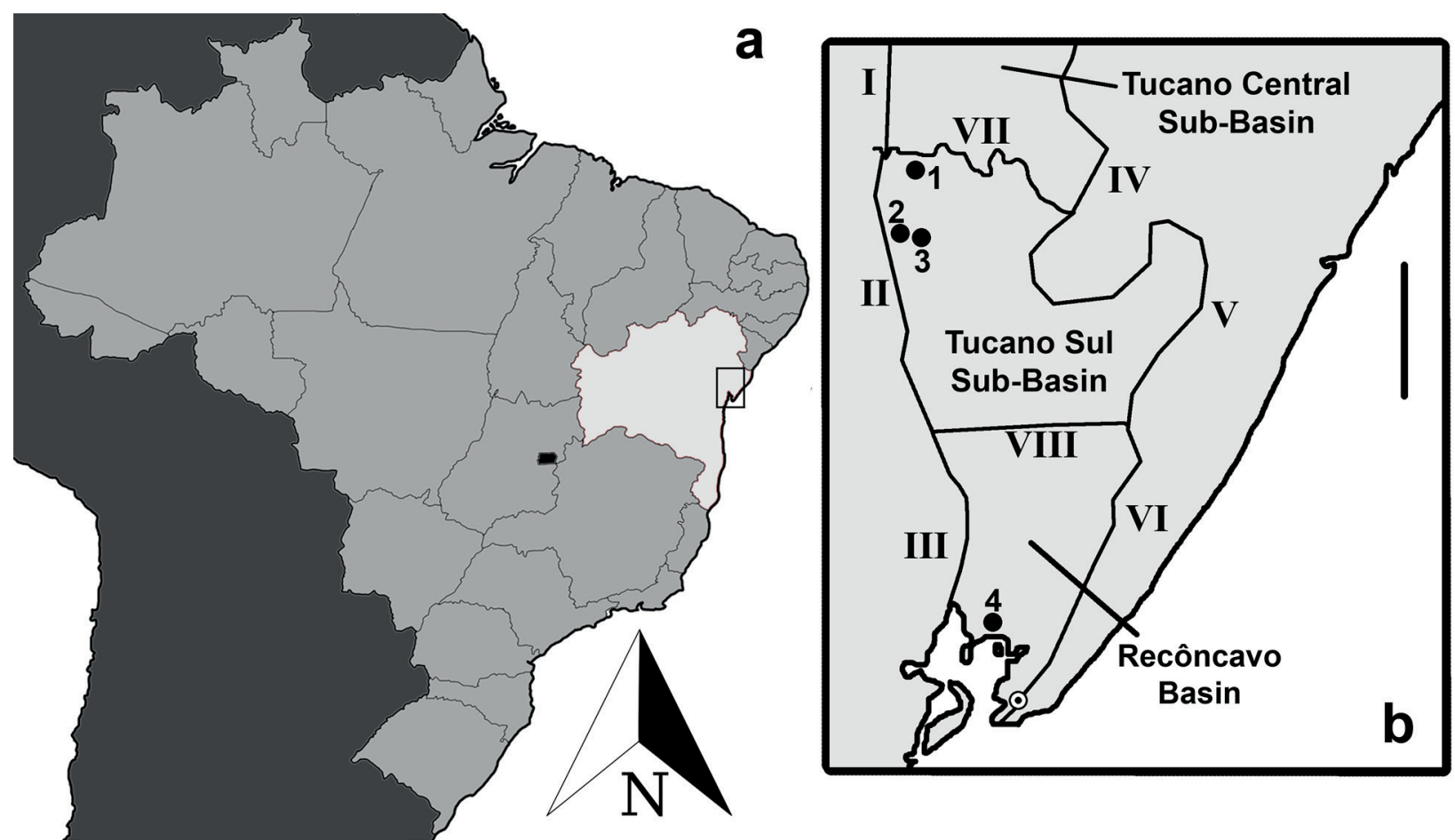

Figure 1 - Locality and studied area map. a) South America map, detaching other South Latinoamerican Countries (dark gray), Brazil (medium gray), State of Bahia (light gray), and Brasilia Federal District (black). Dark box on the State of Bahia is the studied area highlighted in $\mathbf{b}$; and, b) A portion of East and Northeast Bahia State with the Recôncavo-Tucano Basin delimited. Legends: I and II, the discordant contact with the basement or some monocline faults with small displacements; III, Maragojipe Fault; IV, Adustina Fault; V, Inhambupe Fault; VI, Salvador Faults; VII, Accommodation zone where the Itapicuru River flows; VIII, Aporá Height; 1, Tracupá Locality; 2, Quererá Locality; 3, Queimada Grande Locality; 4, Candeias Locality; and, black and white dot is Salvador City. Scale: $50 \mathrm{~km}$.

Museum of Bahia). Fish scales and bone fragments were collected in green shales with sandstone lenses, which were housed in the Geological Museum of Bahia.

Despite the geographic locality information provided above, there is very little precise information regarding its stratigraphy. Also, both Recôncavo Basin and Tucano Sul Sub-Basins present a high quantity of faults (Lima et al. 1981, Gava et al. 1983, Milani and Davison 1988, Bruhn 1999, Costa et al. 2007, Silva et al. 2007), which difficult the precise formation and sedimentary sequence for those localities. In this way, intended to avoid misleading assignments of the stratigraphic horizon for each fossil, they will be here considered as Supergroup Bahia dated from Early Cretaceous.

\section{ANATOMICAL NOMENCLATURE AND COMPARED SPECIES}

The anatomical nomenclature applied here follows Mook (1921), Romer (1956), Salisbury and Frey (2001), Pol (2005), Swartz et al. (2006), Turner (2006), Pol et al. (2012) Leardi et al. (2015), and Godoy et al. (2016).

The species with its specimens and references used on comparisons are listed in Table I.

\section{CROCODYLIFORMES PHYLOGENY AND SYNAPOMORPHIES}

The present work does not aim to provide a new phylogenetic hypothesis for Crocodyliformes species. In this way, our systematic discussion will be based on the consensus topology and synapomorphies provided in Leardi et al. (2015). 
TABLE I

List of the studied species with its respective specimens and references.

\section{SPECIES}

Adamantinasuchus navae Nobre \& Carvalho, 2006

Alligator mississippiensis (Daudin, 1802)

Anatosuchus minor Sereno, Sidor, Larsson \& Gado, 2003

Araripesuchus tsangatsangana Turner, 2006

Araripesuchus gomesi Price, 1959

Armadillosuchus arrudai Marinho \& Carvalho, 2009

Baurusuchus albertoi Nacimento \& Zaher, 2010

Campinasuchus dinizi Carvalho, Teixeira, Ferraz, Ribeiro,

Martinelli, Neto, Sertich, Cunha, Cunha \& Ferraz, 2011

Candidodon itapecuruense Carvalho \& Campos, 1988

Caririsuchus camposi Kellner, 1987

Congosaurus bequaerti Dollo, 1914

Dyrosaurus maghribensis Jouve, Iarochène, Bouya \& Amaghzaz, 2006

Gracilisuchus stipanicicorum Romer, 1972

Itasuchus jesuinoi Price, 1955

Mahajangasuchus insignis Buckley \& Brochu, 1999

Malawisuchus mwakasyungutiensis Gomani, 1997

Montealtosuchus arrudacamposi Carvalho, Vascosellos \& Tavares, 2007

Notosuchus terrestris Woodward, 1896

Oceanosuchus boecensis Hua, Buffetaut, Legall \& Rogron, 2007

Orthosuchus stormbergi Nash, 1968

Peirosaurus tormini Price, 1955

Pholidosaurus purbeckensis (Mansel-Pleydell, 1888)

Pissarrachampsa sera Montefeltro, Larsson \& Langer, 2011

Protosuchus richardsoni (Brown, 1933)

Sarcosuchus hartti (Marsh, 1869)

Sarcosuchus imperator Broin \& Taquet, 1966

Sebecus icaeorhinus Simpson, 1937

Simosuchus clarki Buckley, Brochu, Krause \& Pol, 2000

Stratiotosuchus maxhechti Campos, Suarez, Riff \& Kellner, 2001

Susisuchus anatoceps Salisbury, Frey, Martill \& Buchy, 2003

Terminonaris robusta Mook, 1934

Theriosuchus guimarotae Schwarz \& Salisbury, 2005

Uberabasuchus terrificus Carvalho, Ribeiro \& Avilla, 2004

Yacarerani boliviensis Novas, Pais, Pol, Carvalho, Scanferla, Mones \& Suarez Riglos, 2009

\section{SPECIMENS AND REFERENCES}

Nobre and Carvalho 2006

USNM 312673; USNM 300659; USNM 291916; USNM 544377; DGM 130-RR; DGM 133-RR; M 4864

Sereno and Larsson 2009

Turner 2006

Maisey 1991

Marinho and Carvalho 2009

Vasconsellos et al. 2004, Nascimento and Zaher 2010

Cotts et al. 2017

\section{Nobre 2004}

Kellner 1987, Maisey 1991

Jouve and Schwarz 2004, Schwarz et al. 2006

Jouve et al. 2006

Romer 1972, Lecuona and Desojo 2011

Marinho et al. 2006

Buckley and Brochu 1999

Gomani 1997

Tavares et al. 2015

Pol 2005

Hua et al. 2007

Nash 1975

Marinho et al. 2006

Martin et al. 2016

Godoy et al. 2016

Colbert and Mook 1951

Buffetaut and Taquet 1977

Sereno et al. 2001

Pol et al. 2012

Sertich and Groenke 2010, Hill 2010

D. Riff, unpublished data, Riff and Kellner 2011

Salisbury et al. 2003, Figueiredo and Kellner 2009

\section{Wu et al. 2001}

Schwarz and Salisbury 2005

Vasconsellos et al. 2004, Marinho et al. 2006, F.M.Vasconcellos, unpublished data; CPPLIP 630

Leardi et al. 2015 


\section{SYSTEMATIC \\ CROCODYLIFORMES CLARK, 1986 MESOEUCROCODYLIA WHETSTONE AND WHYBROW, 1983}

\section{MESOEUCROCODYLIA INDET.}

Gen. et sp. indet.

Material: MCT 1860-R, a well-preserved osteoderm (Figure 2a, b, c).

Locality: Tracupá Locality (Figure 1b, locality 1), Supergroup Bahia (Early Cretaceous).

Description: MCT 1860-R consists on an osteoderm with rectangular shape and rounded edges. Its maximum width is $120 \mathrm{~mm}$ and its maximum length is $100 \mathrm{~mm}$ (Figure $2 \mathrm{a}, \mathrm{b}$ ). The material is broken on its both lateral and medial margins making it difficult to infer its real measure and shape. The ornamentation of MCT 1860-R is well-preserved (Figure 2a, b, c), though the margin is cracked losing its lateral region and a large break goes by its posterior edge at its medial region. MCT $1860-\mathrm{R}$ does not present any keel on its dorsal surface. However, due to the broken margins, we cannot assure the presence of a more lateralized keel. The MCT $1860-\mathrm{R}$ is thicker medially than anterior and posterior margins (Figure 2c), having almost $20 \mathrm{~mm}$. In dorsal surface, there is large and deep irregular rounded pits. The ornamentation pattern has the anterior pits smaller than the medial and posterior ones, being the larger pits distributed lateromedially along the medial transverse section of the longitudinal axis (Figure 2a). The anterior margin shows a smooth articular facet in all of its extension (facies articularis externa, Salisbury and Frey 2001; Figure 2a), which is inclined, being one portion more anteriorly elongated than its opposed (Figure 2a). Similar structures were named as the anteromedial process (Brochu 2004) or anterolateral process (Brochu et al. 2012), which are anterior projections of the articular surface, resulting on a semilunar convexity. Note that the Brochu's anterior process are not homologue with the lateroanterior process, or peg-like process, described by Salisbury and Frey (2001; processus articularis). This implies that the character 96 of Leardi et al. (2015) mixes two biologically independent features. Therefore, MCT 1860-R presents a well-developed anterior projection of the articular surface, considering the presence of the processus articularis, as a peg-like process forming a stylofoveal joint (see Salisbury and Frey 2001), cannot be assured due to the marginal cracks of the osteoderm. The posterior line of the articular face is straight (Figure 2a). In ventral view (Figure 2b), MCT 1860-R is very smooth with the exception of two longitudinal concave lines, and three small and oval nutritional foramina. Regarding the internal structures visible on medial section (Figure 2c), MCT 1860-R presents a succession of a slightly cancellous bone tissue that is located between the ventral and dorsal cortex, which consists of two narrow and compact bone tissues.

Comparisons: The general osteoderm shape is not conclusive due to its fractures. However, in MCT 1860-R we expect a broad than long rectangular or oval shape, feature widely distributed among crocodyliforms (see Leardi et al. 2015). MCT 1860$\mathrm{R}$ differs strongly from general notosuchians and some neosuchians -mainly the extant eusuchiansin a well-marked ornamentation with profound pits and the semilunar convexity of the facies articularis externa. MCT 1860-R ornamentation is very particular due to the presence of large, rounded, irregular and profound pits, which are the smallest ones anteriorly and the largest ones along the medial transverse section of the longitudinal axis. This ornamentation differs from the observed in other crocodyliforms that have small pits uniformly distributed such as Araripesuchus Price, 1959 (Maisey 1991, Turner 2006), Caririsuchus camposi Kellner, 1987 (Kellner 1987, Maisey 1991), Goniopholis Owen, 1841 (Salisbury and Frey 2001), Itasuchus jesuinoi Price, 1955 (Marinho et al. 2006), Montealtosuchus arrudacamposi Carvalho, 


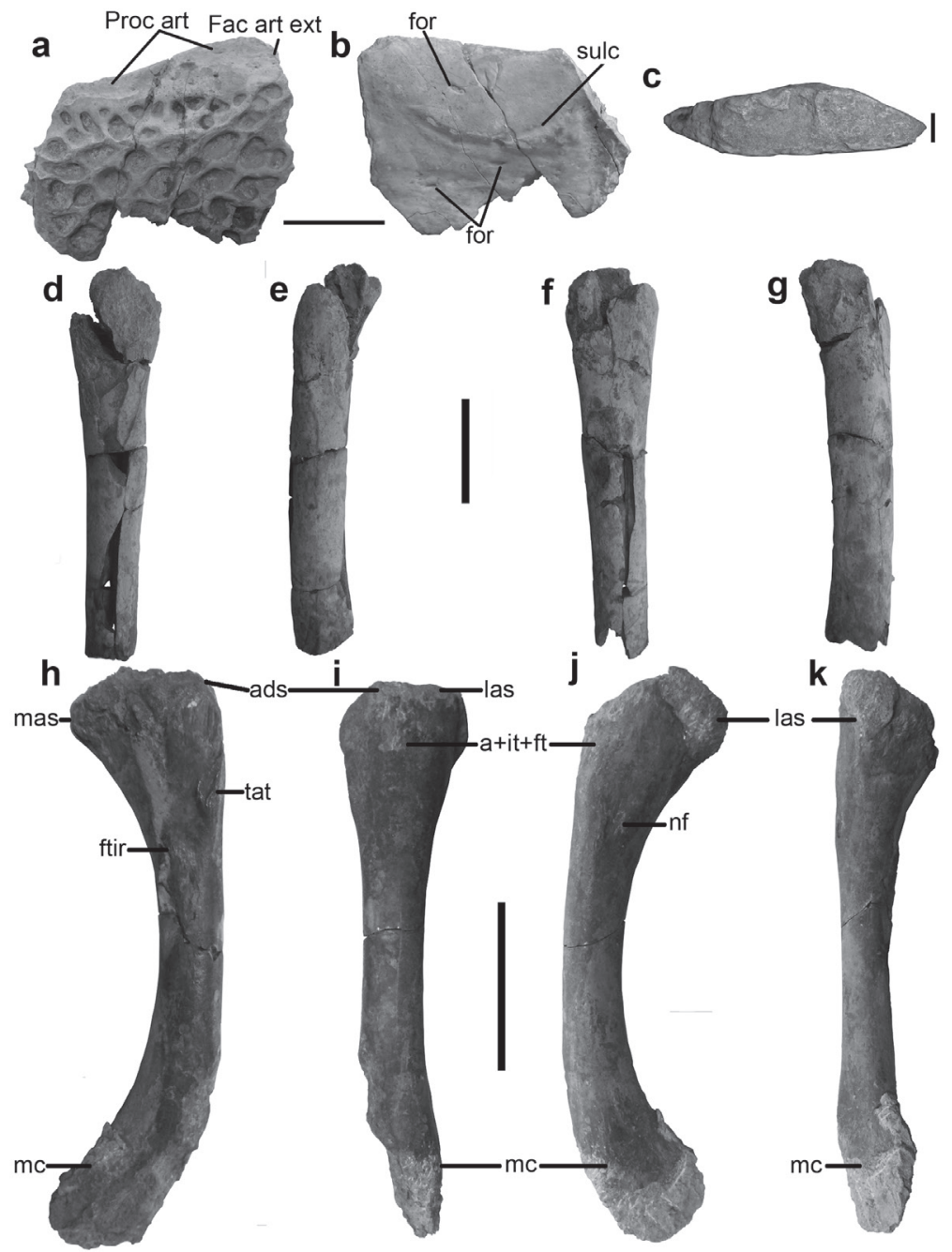

Figure 2 - New Crocodyliformes specimens. An osteoderm (MCT 1860-R). a) dorsal view; and, b) ventral view; c) medial view. A fibula (MCT 1859-R): d) anterior view; e) lateral view; f) posterior view; and $\mathbf{g}$ ) medial view. A left tibia (MCT 1862-R): h) anterior view; i) lateral view; j) posterior view; and, k) medial view. Abbreviations: a + it + ft, Mm. ambiens, iliotibialis 1-3, and femorotibialis; ads, anterolateral surface; Fac art ext: Facies articularis externa; For, foramina; ftir, $M$ flexor tibialis internus insertion ridge; las, articular lateral surface; mas, medial articular surface; mc, medial condyle; nf, nutrient formanen; Proc art, processus articularis; Sulc, sulcus and, tat, $M$ tibialis anterior tuberosity. Scale a, b and $\mathbf{d}$ to $\mathbf{k}: 50 \mathrm{~mm}$; Scale $\mathbf{c}: 10 \mathrm{~mm}$.

Vascosellos \& Tavares, 2007 (Tavares et al. 2015), Oceanosuchus boecensis Hua, Buffetaut, Legall \& Rogron, 2007 (Hua et al. 2007), Peirosaurus tormini Price, 1955 (Marinho et al. 2006), Pholidosaurus purbeckensis (Mansel-Pleydell, 1888) (Martin et al. 2016), Simosuchus clarki Buckley, Brochu, Krause \& Pol, 2000 (Hill 2010),
Susisuchus anatoceps Salisbury, Frey, Martill \& Buchy, 2003 (Salisbury et al. 2003), Terminonaris robusta Mook, 1934 (Wu et al. 2001), Theriosuchus guimarotae Schwarz \& Salisbury, 2005 (Schwarz and Salisbury 2005), Uberabasuchus terrificus Carvalho, Ribeiro \& Avilla, 2004 (Marinho et al. 2006), and the osteoderms described by Young et 
al. (2016). MCT 1860-R differs from the dyrosaurid osteoderms described by Hastings et al. (2014), which does not present any pit ornamentation, and also differ from the irregular lateromedial distributional patter observed in Sarcosuchus Broin \& Taquet, 1966 (Buffetaut and Taquet 1977, Sereno et al. 2001). The absence of the medial dorsal crest in MCT 1860-R is shared with Oceanosuchus boecensis (Hua et al. 2007), Pholidosaurus purbeckensis (Martin et al. 2016) and Terminonaris robusta (Wu et al. 2001). Regarding the spine-like processus articularis observed in Oceanosuchus boecensis (Hua et al. 2007), Pholidosaurus purbeckensis (Martin et al. 2016), and Sarcosuchus (Buffetaut and Taquet 1977, Sereno et al. 2001), its presence on MCT $1860-\mathrm{R}$ is not conclusive due to its fragmentary margins. The MCT 1860-R shares the semilunar convexity of the articular facet with Eothoracosaurus mississippiensis Brochu, 2004, Borealosuchus threeensis Brochu, Parris, Grandstaff, Denton Jr \& Gallagher, 2012 (Brochu 2004, Brochu et al. 2012) and "Leidyosuchus" sp. from Schwimmer (2002). However, MCT 1860$\mathrm{R}$ possesses this convexity more developed than those specimens.

Comments: MCT 1860-R based on the broad than long shape, ornamentation and a semilunar convexity of the articular facet shared with some Neosuchia species, this specimen could be related to semi-aquatic neosuchian species.

\section{MESOEUCROCODYLIA INDET.}

Gen. et sp. indet.

Material: MCT 1859-R, a left fibula (Figure 2d, e, f, $g$ ).

Description: The left fibula (MCT 1859-R) is a partially preserved elongated bone (Figure $2 \mathrm{~d}$, e, $\mathrm{f}, \mathrm{g}$ ), which are recognized the medial and part of the proximal end. The bone is hollow with relatively thick bone (Figure 2d, e, f, g). In general, the external surface of the fossil is well-preserved
(Figure 2d, e, f, g). The MCT 1859-R gets thinner in its distal preserved part (Figure 2d, e, f, g). The fibular shaft is subcircular in transversal section at its midshaft, being compressed anteroposteriorly and, therefore, enlarged lateromedially in its proximal end (Figure 2d, e, f, g). MCT 1859-R presents a slightly anterior curvature in its lateral view (Figure 2e, g). The iliofibularis trochanter is not preserved as a crest (Figure 2d, e, f, g).

Comparison: MCT 1859-R the proximal end is slightly curved anteriorly differing from the almost straight proximal end of the Orthosuchus stormbergi Nash, 1968 (Nash 1975), Malawisuchus mwakasyungutiensis Gomani, 1997 (Gomani 1997), and Terminonaris robusta (Wu et al. 2001). The proximal end is slightly compressed anteroposteriorly, but not compressed as in Araripesuchus tsangatsangana Turner, 2006 (Turner 2006), Baurusuchus albertoi Nascimento \& Zaher, 2010 (Nascimento and Zaher 2010),Mahajangasuchus insignis Buckley \& Brochu, 1999 (Buckley and Brochu 1999) and Malawisuchus mwakasyungutiensis (Gomani 1997).

Comments: regarding phylogenetic characters for Crocodyliformes there are only three intended to account for fibula morphology (see characters 272, 282 and 425 in Leardi et al. 2015). From those, none of them is synapomorphic for any Crocodyliformes group. In MCT 1859-R, due to its fragmentary status, only its straight margin distally to the iliofibularis trochanter (character 282) could be identified. However, this feature is widely distributed among different crocodyliforms groups. Therefore, MCT 1859-R is a fibula with the circular medial transverse section, a slightly compressed and curved proximal end as in other Mesoeucrocodylia. Further materials and new contributions are needed to achieve a better phylogenetic position of this specimen. 


\section{MESOEUCROCODYLIA INDET.}

Gen. et sp. indet.

Material: MCT 1862-R, a left tibia (Figure 2h, i, $\mathrm{j}, \mathrm{k}$ ).

Locality: Candeias Locality (Figure 1b, locality 4), Supergroup Bahia (Early Cretaceous).

Description: MCT 1862-R is a relatively wellpreserved fossil with approximately $180 \mathrm{~mm}$ in height (Figure 2h, i, j, k). The proximal and distal surface are severely worn and broken, with the complete loss of the lateral condyle and distal portions of the medial condyle (mc; Figure 2h, i, j, $\mathrm{k})$. The tibia is cylindrical, mainly on its midshaft, with expansions both on proximal and distal regions (Figure 2h, i, j, k). The proximal region, which contacts the distal surface of the femur, has a badly preserved medial articular surface (mas; Figure 2h), anterolateral surface (ads; Figure 2h, i), and lateral articular surface (las; Figure 2h, i, j). In anterior and posterior view, MCT 1862-R has a developed convexity at its medial surface, which is the result of the distal and proximal curvature of the proximal and distal ends, respectively (Figure 2h, $\mathrm{i}, \mathrm{j}, \mathrm{k}$ ). Contrasting with this curvature, the lateral region of the medial shaft is straight (Figure 2h, i). In anterior view, there is a well-marked roughness for the insertion of M. flexor tibialis internus (ftir; Figure 2h). Proximolaterally to the roughness for the insertion of $M$. flexor tibialis internus, there is an additional well-developed roughness, here recognized as the tuberosity for the $M$. tibialis anterior (tat; Figure 2h). In lateral view, at the final proximal region of the shaft, there are several wellmarked scars for the Mm. ambiens, iliotibialis 1-3, and femorotibialis. In posterior view, above the medial shaft there is a sloping nutritional foramen (nf; Figure 2j). In the distal end, the medial condyle presents only its medial surface preserved (Figure $2 \mathrm{j})$. The medial condyle is expanded lateromedially (Figure 2h, i, j, k).
Comparisons: The badly preserved medial articular surface (mas; Figure 2h) of the tibia MCT 1862-R is well-developed, being located on the anteromedial surface which projects medially as in Congosaurus bequaerti Dollo, 1914 (Jouve and Schwarz 2004, Schwarz et al. 2006), Mahajangasuchus insignis (Buckley and Brochu 1999), Protosuchus richardsoni (Brown, 1933) (Colbert and Mook 1951), Simosuchus clarki (Sertich and Groenke 2010) and Terminonaris robusta (Wu et al. 2001). This projection and the slope of the shaft makes the medial surface concave in anterior and posterior view, as observed in Congosaurus bequaerti (Jouve and Schwarz 2004, Schwarz et al. 2006), Mahajangasuchus insignis (Buckley and Brochu 1999), Pissarrachampsa sera Montefeltro, Larsson \& Langer, 2011 (Godoy et al. 2016), Protosuchus richardsoni (Colbert and Mook 1951), Simosuchus clarki (Sertich and Groenke 2010) and Terminonaris robusta (Wu et al. 2001). Opposed to this concavity, MCT 1862-R is straight on its lateral surface shaft (Figure $2 \mathrm{~h}, \mathrm{i}$ ), as observed in Congosaurus (Jouve and Schwarz 2004, Schwarz et al. 2006), Mahajangasuchus insignis (Buckley and Brochu 1999), Simosuchus clarki (Sertich and Groenke 2010) and Terminonaris robusta (Wu et al. 2001). The anterolateral surface (ads; Figure 2h, i) and lateral articular surface (las; Figure 2h, i, j) are not well-preserved for comparisons. In MCT $1862-$ $\mathrm{R}$ the medial condyle is slightly directed anteriorly, being proximodistally aligned with the medial articular surface, as in Mahajangasuchus insignis (Buckley and Brochu 1999). The crest for insertion of M. flexor tibialis internus (ftir; Figure $2 \mathrm{~h}$ ) is well-developed as in Mahajangasuchus insignis (Buckley and Brochu 1999), Pissarrachampsa sera (Godoy et al. 2016) and Simosuchus clarki (Sertich and Groenke 2010). However, it differs from Pissarrachampsa sera in having a small crest for muscular insertion (Godoy et al. 2016). The crest for insertion of the M. tibialis anterior (tat; Figure 2h) is displaced distally in relation with 
Simosuchus clarki (Sertich and Groenke 2010), resembling the morphology of Mahajangasuchus insignis (Buckley and Brochu 1999).

Comments: Based on Leardi et al. (2015) there are three specific characters for tibia, two of them are related to the configuration of the shaft (characters 335 and 336 from Leardi et al. 2015) and the third describes the projections of the tibial articular surface at the distal end (character 337 from Leardi et al. 2015), but none of those characters are synapomorphies (see Leardi et al. 2015). Those related with the shaft were described and compared earlier. The character related with the distal articular surface cannot be identified on MCT 1862-R due its fragmentary state. Therefore it is not possible to assign this specimen within any Mesoeucrocodylia group until new materials related with MCT 1862-R are discovered, or new tibia characters are recovered as synapomorphies.

\section{MESOEUCROCODYLIA INDET.}

Gen. et sp. indet.

Material: MCT 1861-R, a distal end of a radius, a radiale and three phalangeal bones from the right forelimb.

Locality: Queimada Grande Locality (Figure 1b, locality 3), Supergroup Bahia (Early Cretaceous).

Description: MCT 1861-R is a series of fragmented and isolated, but associated, bones from the distal end of the right arm, being a distal end of a radius, an almost complete radiale, three phalangeal bones and one ungueal. The distal end of the radius (Figure $3 \mathrm{a}, \mathrm{b}, \mathrm{c}$ ) has some abrasion on its external surface (Figure 3b), being its extremities slightly rounded (Figure 3a, b, c). This bone is $80 \mathrm{~mm}$ in its major longitudinal length at the distal end (distal view), and $60 \mathrm{~mm}$ in tall. In distal view, the concavity for ulnar articulation is relatively shallow (Figure $3 \mathrm{a}, \mathrm{c})$, anterior to this concavity there is a welldeveloped crest, which is laterally compressed and points anterolaterally (Figure $3 \mathrm{c}$ ). This crest extends proximally, but its end cannot be assured due to its fragmentary condition. The transversal section where the crest is present is oval (Figure 3). This crest receives the muscular attachment of the extensor and flexor region of antebrachium, such as musculus pronator teres, musculus supinator and musculus extensor carpi radialis brevis pars radialis (Meers 2003). The distal view of the radius presents an ample and subtriangular radiale articular surface (Figure 3c).

The radiale is $70 \mathrm{~mm}$ in height, with the proximal end damaged laterally (Figure 3d, e, f, g). The bone presents some small breaks, mainly at its distal end, and present some abrasion and rounded surfaces (Figure 3d, e, f, g, h, i). The radiale thinner portion is its midshaft, hourglass shape; this shape is result of the well-developed articular surface for the ulna that projects medially and the expansion of the distal end (Figure 3d, f). The articular surface for the ulna (asu) is a rounded smooth surface located at the lateral portion of the proximal region. In lateral view, its lateral margin slopes anteriorly, becoming an inclined articular surface (Figure 3e). Lateral to the articular surface for the ulna there is a shallow concavity that corresponds topographically to the know depression for the origin of $M$. flexor digiti quinti pars superficialis et profundus (Leardi et al. 2015). In anterior view, a well-marked subtriangular crest, with the basal region at the distal end of the radiale and the apical portion reaching its midshaft, corresponds to the anterior crest of the radiale (acre; Figure 3f, g). This crest is interpreted as the origin of the M. extensor digiti II superficialis and M. extensor pollicis superficialis et indicis proprius (Leardi et al. 2015). The proximal end presents a subtriangular shape, being wider lateromedially than longer anteroposteriorly. Its posterior margin is linear, while the anterior one has a small anterior process (Figure 3i). The proximal region is broke on its lateral portion, with loss of a portion of the articular surface for the radius. The radiale distal end is subcircular and shallow concave for the 
articulation with metacarpal I and a distal carpal (Figure $3 h$ ).

The three phalanges, which are relatively well-preserved rounded surfaces and the proximal process are not completely preserved (Figure 3j, $\mathrm{k}, 1)$. Those phalanges, probably correspond to the first of digit IV or V (Figure 3j), digit II or III (Figure 3k) and digit I (Figure 31). Although, some small differences between those phalanges are present. They have approximately 60 to $70 \mathrm{~mm}$ in anteroposterior length, with a concave ventral region and an almost horizontal dorsal region. The ventral and dorsal proximal processes for the metacarpals, when preserved, are well-developed, the distal region is rounded with a medial sulcus in proximal view, and the proximal region is larger than distal one.

The ungueal has almost $40 \mathrm{~mm}$ in length, which is robust regarding its lateromedial length (Figure $3 \mathrm{~m})$. In dorsal view, its margins are straight until the final third where they converge to its longitudinal axis, reaching its minimum width. The distal region is thinner than the proximal one (Figure $3 \mathrm{~m}$ ). The medial surface is broken. The proximal end does not preserve its articular region. Also, in proximal view, is sub-circular, being slightly compressed dorsoventrally. In lateral view, there is a medial sulcus that reaches two third of the ungueal (Figure $3 \mathrm{~m})$. This sulcus presents a uniform size, reaching its minimum size only at its most anterior end. The ungueal dorsal surface is convex, being almost straight at its most proximal region (Figure $3 \mathrm{~m}$ ). Its ventral surface is slightly concave (Figure $3 \mathrm{~m}$ ).

Comparisons: The radius (MCT 1861-R) has a radiale articular surface wide and irregular, as in Simosuchus clarki (Sertich and Groenke 2010). The ulnar articulation is shallow as in Baurusuchus albertoi (Nascimento and Zaher 2010), Notosuchus terrestris Woodward, 1896 (Pol 2005), Pissarrachampsa, sera (Godoy et al. 2016) and Simosuchus clarki (Sertich and Groenke 2010).
The well-developed anterolateral crest is similar to the observed in the Notosuchia species.

The radiale is short in height and robust differing from Araripesuchus tsangatsangana (Turner 2006), Mahajangasuchus insignis (Buckley and Brochu 1999), and Sebecus icaeorhinus Simpson, 1937 (Pol et al. 2012), which are taller and thinner. Also, differs from Terminonaris robusta (Wu et al. 2001), which the articular surface for the ulna projected laterally. The articular surface for the ulna is circular as in Congosaurus bequaerti (Jouve and Schwarz 2004, Schwarz et al. 2006) but differing from the oval, proximodistally elongated, surface seems in all other studied species (Figure 4). The articular surface for the ulna has its lateral margin inclined anteriorly, a similar, but less inclined, this condition can be observed in Baurusuchus albertoi (Nascimento and Zaher 2010) and Notosuchus terrestris (Pol 2005). The anterior crest in MCT 1861-R has a robust distal end, and its proximal portion is lateromedially large, resulting on a wellmarked subtriangular crest. This crest differs from all other species which is thin and proximodistally long (Figure 4).

Regarding the three phalanges with a uniform concave ventral surface differs from the irregular concave ventral surface (the robust proximal articulation gets thinner distally, forming a neck, which expands ventrally until the distal end) observed in Alligator mississippiensis (Daudin, 1802), Baurusuchus albertoi (Nascimento and Zaher 2010), Mahajangasuchus insignis (Buckley and Brochu 1999), Simosuchus clarki (Sertich and Groenke 2010), and Stratiotosuchus maxhechti Campos, Suarez, Riff \& Kellner, 2001 (Riff and Kellner 2011).

The MCT 1861-R ungueal is more robust lateromedially in comparison with the studied species. Also, the dorsal convexity and ventral concavity are more slender differing from the welldeveloped curvature as observed in Baurusuchus albertoi (Vasconsellos et al. 2004), Campinasuchus 

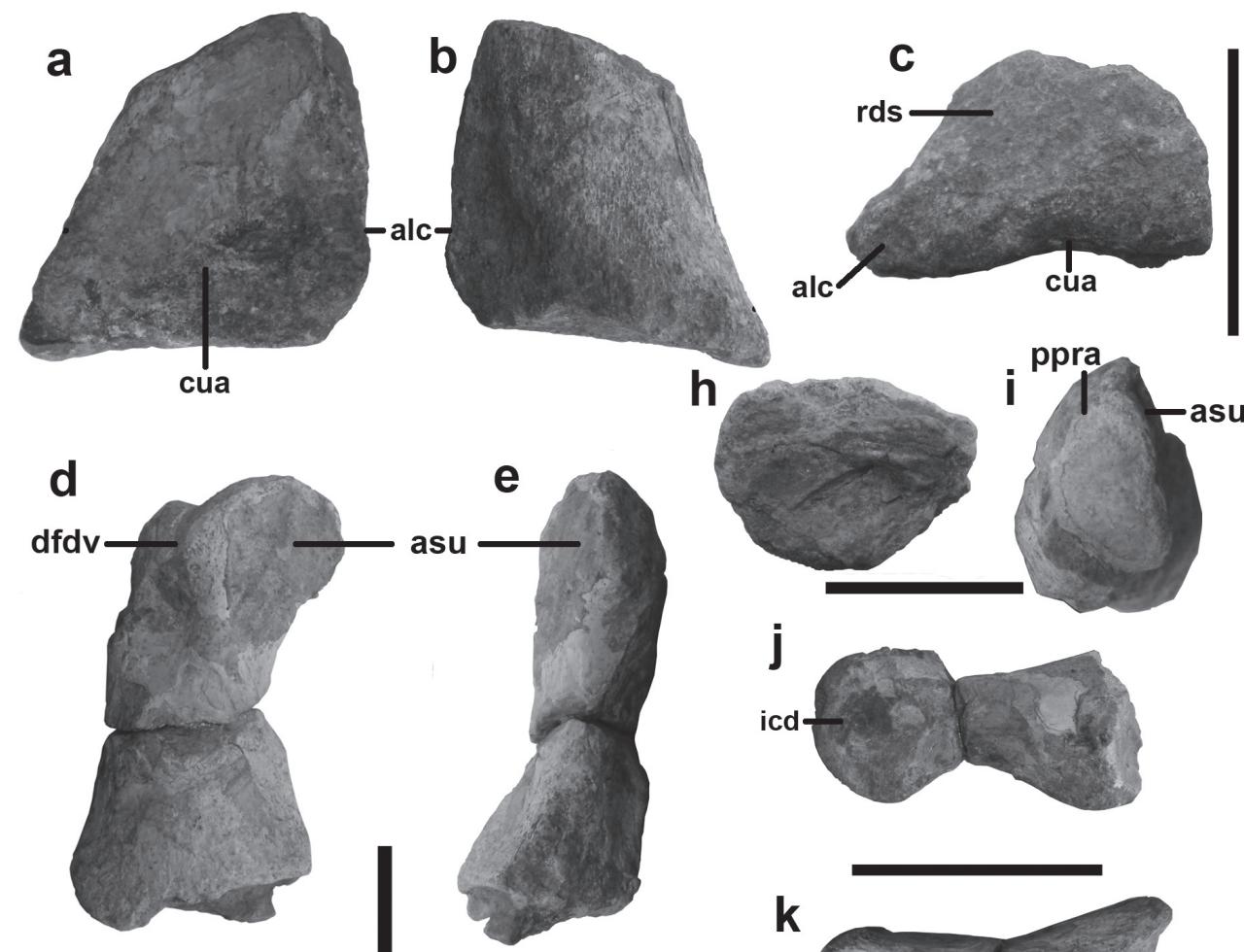

ppra
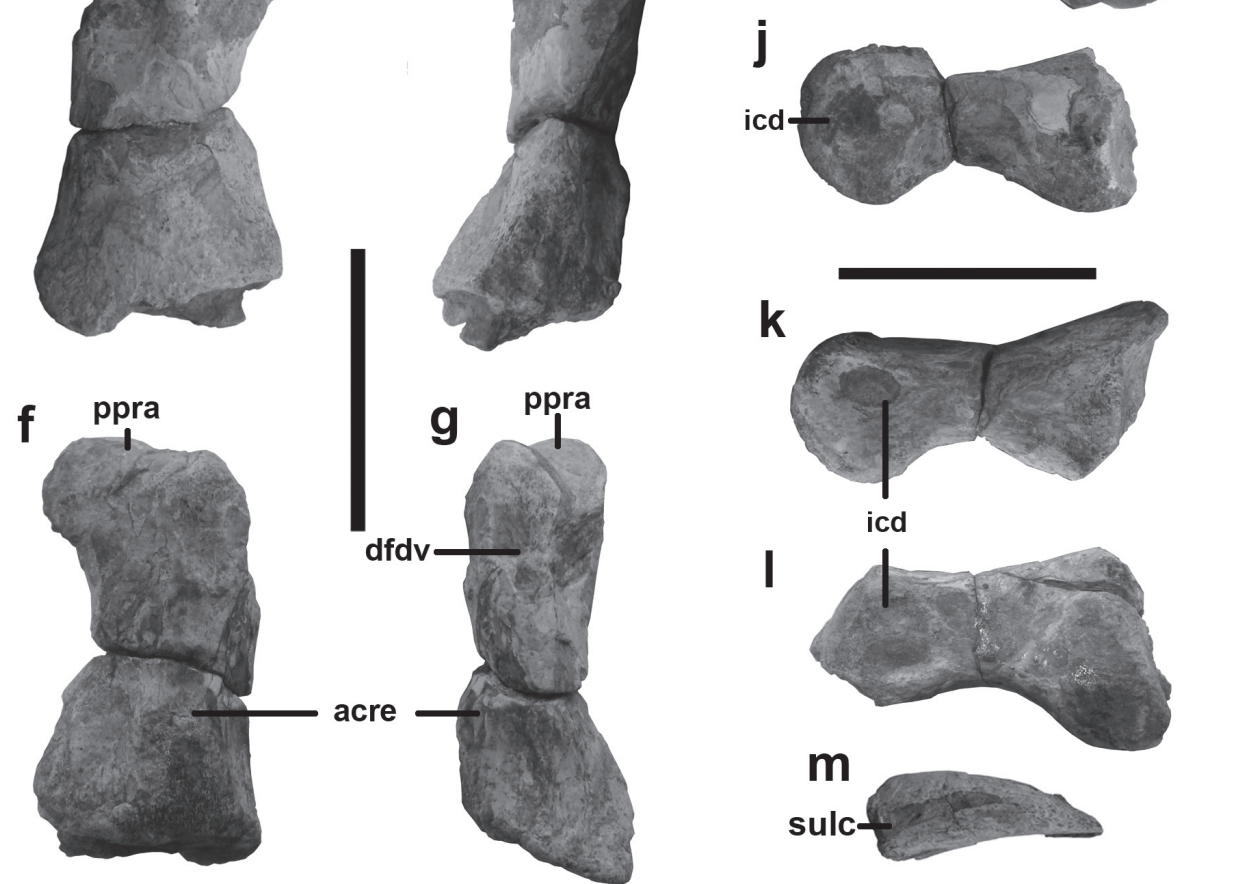

m

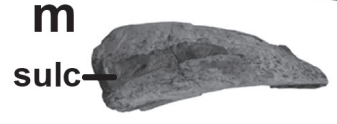

Figure 3 - A right autopodium (MCT 1861-R). Distal end of radius in a) lateral, b) medial, and c) proximal views; radiale in d) posterior, e) lateral, f) anterior, g) medial, h) distal, and i) proximal views; $\mathbf{j}, \mathbf{k}$ and $\mathbf{l}$ ) phalangeal bones in lateral view; and, m) ungueal in lateral view. Abbreviations: acre, anterior crest of the radiale; alc, anterolateral crest; asu, articular surface for the ulna; cua, concavity for articular concavity; $\mathbf{d f d v}$, depression for the origin of the M flexor digiti quinti pars superficialis et profundus; icd, M. interossei circular depression; ppra, proximal process of the radiale; rds, radiale articular of radius; and, Sulc, sulcus. All scales: $50 \mathrm{~mm}$.

dinizi (Cotts et al. 2017), Simosuchus clarki (Sertich and Groenke 2010), Stratiotosuchus maxhechti (Riff and Kellner 2011), Uberabasuchus (Vasconsellos et al. 2004), and Yacarerani boliviensis Novas, Pais, Pol, Carvalho, Scanferla, Mones \& Suarez Riglos, 2009 (Leardi et al. 2015).
The lateral sulci is similar to the less-developed sulci observed in the Baurusichidae Price, 1945 (Baurusuchus albertoi; Campinasuchus dinizi and Stratiotosuchus maxhechti), but differs from the foramina-like Yacarerani boliviensis (Leardi et al. 2015) and Simosuchus clarki (Sertich and Groenke 
2010) and the linear sulci along all the medial surface of the Anatosuchus minor Sereno, Sidor, Larsson \& Gado, 2003 (Sereno and Larsson 2009).

Comments: Based on phylogenetic characters proposed by Leardi et al. (2015) there are no specific characters for radio and phalanx. The MCT 1861-R could be codified only for radiale (characters 110, 117, 318 to 322 and 421) and ungueal (character 422). From those only the character 319 was recovered as synapomorphies for Ziphosuchia after the exclusion of Libycosuchus Stromer, 1914 and Candidodon Carvalho \& Campos, 1988 (see Leardi et al. 2015). This character accounts for a proximodistally elongated articular surface for the ulna on the radial. Therefore, MCT 1861-R could not be considered a ziphosuchian crocodyliform. Some additional similarities shared with Notosuchians must be highlighted: 1) radius with wide and irregular radiale articular surface; 2) radio has a shallow ulnar articulation; 3) well-developed anterolateral crest in the radio; and 4) radiale with the lateral margin of the articular surface for the ulna inclined anteriorly. Furthermore, MCT 1861-R shares with some neosuchians the short and robust radiale with the circular articular surface for the ulna. The MCT 1861-R has two distinct features in the radiale: 1) the inclination of the articular surface for the ulna, which is more accentuated than the notosuchians; and, 2) the anterior crest has the exclusive sub-triangular and robust configuration. In this way, MCT 1861-R share features with distinct groups (e.g., Neosuchia Benton \& Clark, 1988 and Notosuchia Gasparini, 1971), thus a definitive systematic designation is only viable until new materials are recovered.

\section{DISCUSSION AND CONCLUSION}

Based on crocodyliform phylogenetic literature, there are few proposed postcranial synapomorphies for the greater clades (e.g., Neosuchia and Notosuchia) compared to the cranial ones. Some authors can argue that the postcranial was not as informative as the skull, but the crescent number of postcranial fossil finds and characters propositions are visible on literature (see Leardi et al. 2015) could indicate the opposed. However, despite the more recent attempts for postcranial descriptions and synapomorphies identifications (e.g., Pol 2005, Pol et al. 2012, Leardi et al. 2015), more works are in need, mainly for non-Notosuchian clades, aiming to summarize all morphological variation identified on postcranial bones as characters. For example, there are no specific characters for radius, which is a bone with relative abundance in the fossil record and present interesting morphological variations between species (see Systematic). Also, more detailed descriptions of postcranial bones as made for are in need to improve our knowledge in crocodyliforms evolution, e.g., Baurusuchus albertoi, Caipirasuchus paulistanus, C. montealtensis, Campinasuchus, Notosuchus, Pissarrachampsa, Sebecus, Simosuchus, Stratiotosuchus, and Yacarerani. In consequence of the reduced number of postcranial synapomorphies for limb bones and osteoderms and the fragmentary status of the described material, no further categorization besides Mesoeucrocodylia was made.

The Early Cretaceous of Bahia has only two species described, one Pholidosauridae, Sarcosuchus hartti, and one Crocodylia (Gavialoidea), such as Thoracosaurus bahiensis. However, nowadays Thoracosaurus bahiensis is considered a nomen dubium (Souza et al. 2015). The four new specimens described cannot be directly assigned to any previous know species from Early Cretaceous, applying our crocodyliforms diversity knowledge in the region. Regarding the Brazilian Early Cretaceous the crocodyliforms diversity consists, until now, in two notosuchian species (Araripesuchus gomesi Price, 1959 and Caririsuchus camposi) and two neosuchian species (Susisuchus anatoceps and Susisuchus 

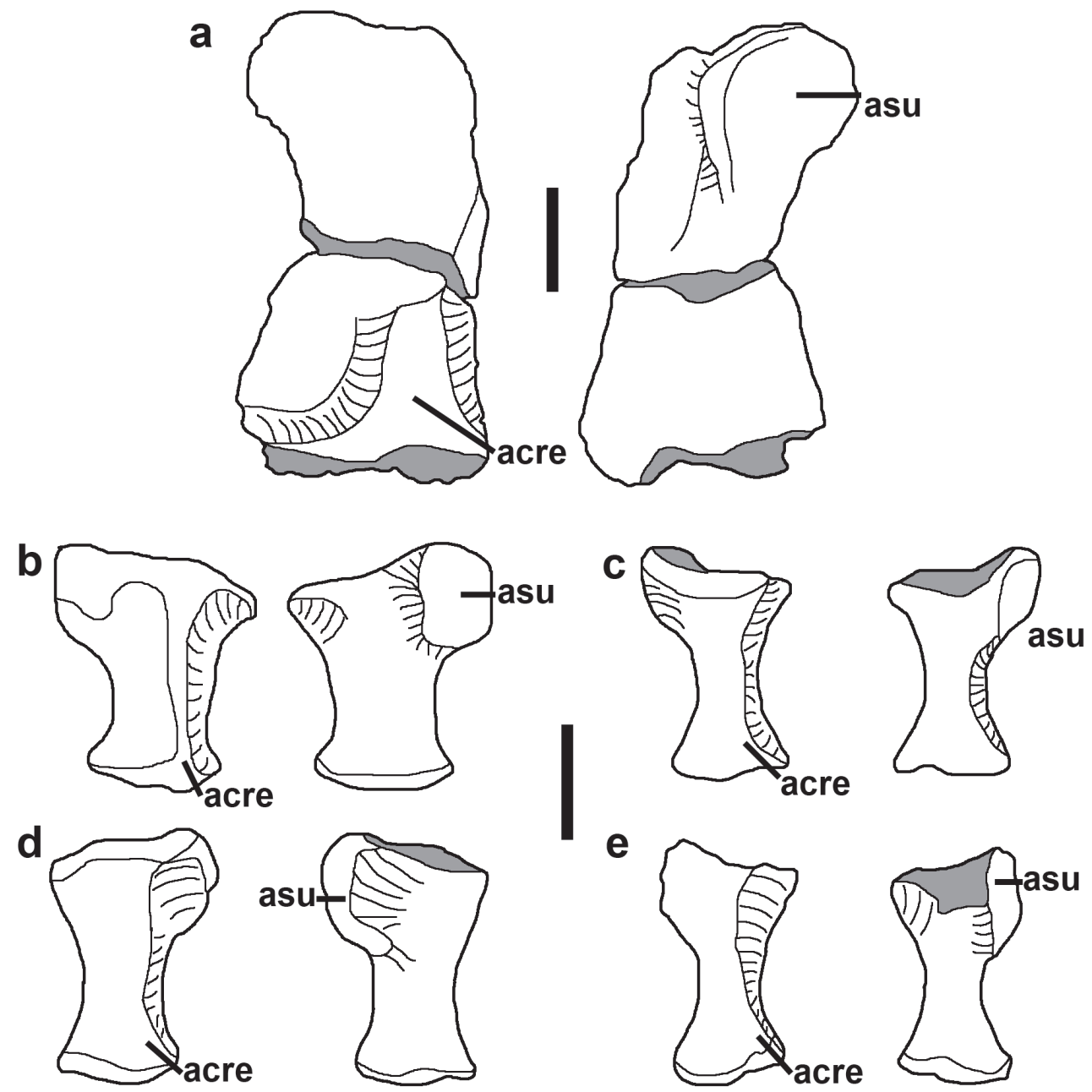

Figure 4 - Schematic comparisons of some Crocodyliformes radiale in anterior and posterior views respectively. All figured radiale are elements from the right autopodium, with exception of Yacarerani. radiale, which belongs to the left autopodium a) MCT 1861-R; b) Congosaurus (based on Schwarz et al. 2006); c) Simosuchus (based on Sertich and Groenke 2010); d) Yacarerani (based on Leardi et al. 2015); and, e) Baurusuchus albertoi (based on Nascimento and Zaher 2010). Abbreviations: acre, anterior crest of the radiale; asu, articular surface for the ulna. All scales: $20 \mathrm{~mm}$.

jaguaribensis Fortier \& Schultz, 2009) from Araripe Basin.

The crocodyliforms diversity in Early Cretaceous of Brazil -and particularly from Recôncavo-Tucano Basins- is increased with these four new specimens. From those, the specimen MCT 1860-R has some morphological similarities with semi-aquatic neosuchians, being considered a new morphotype of this group in Early Cretaceous of Brazil due the differences observed with Sarcosuchus hartti and Susisuchus species. The specimen MCT 1861-R has an uncertain position within Mesoeucrocodylia, butas it shares similarities with both Neosuchia and Notosuchia this specimen can be considered also a new morphotype as it differs markedly from the other known species. The specimens MCT 1859-R and MCT 1862-R are too fragmentary for any further comments. Therefore based on the know crocodyliforms species from Brazilian Early Cretaceous we present here at least two new morphospecies, which increases our diversity knowledge of these group in this region. 
Further associable materials are in need for the proper specific identification of those specimens. Future works on the region will help to elucidate the crocodyliforms diversity for Early Cretaceous and has potential to better understand the explosive diversification of the group in Late Cretaceous.

\section{ACKNOWLEDGMENTS}

We would like to thank Rodrigo Machado Departamento Nacional de Produção Mineral (DNPM), curator of Paleontology of the Museu de Ciências da Terra - Companhia de Pesquisa de Recursos Minerais (CPRM), for access to the studied material. Thanks to Kamila L.N. Bandeira $(\mathrm{MN})$ and Borja Holgado (MN) for revision and comments on earlier drafts of this manuscript. Thanks to André E.P. Pinheiro, (FFP/UERJ) for anatomical discussion and identification of the material. Also, thanks for Juan Martín Leardi (Universidad de Buenos Aires), Christopher A. Brochu (University of Iowa) and the other two anonymous reviewers for comments that improved this work. For general advisements, RGS thanks to Alexander W.A. Kellner (MN) and Douglas Riff (UFU).

\section{REFERENCES}

ALLPORT S. 1860. On the discovery of some fossil remains near Bahia in South America. Q J Geol Soc London 16: 263-266

BROCHU C. 2004. A new Late Cretaceous gavialoid rocodylian from Eastern North America and the phylogenetic relationships of thoracosaurs. J Vertebr Paleontol 24: 610-633.

BROCHU C, PARRIS DC, GRANDSTAFF BS, DENTON JR RK AND GALLAGHER WB. 2012. A New Species of Borealosuchus (Crocodyliformes, Eusuchia) from the Late Cretaceous-Early Paleogene of New Jersey. J Vertebr Paleontol 32: 105-116.

BRUHN CHL. 1999. Reservoir Architecture of DeepLacustrine Sandstones from the Early Cretaceous Recôncavo Rift Basin, Brazil. AAPG Bull 83: 1502-1525.

BUCKLEY GA AND BROCHU CA. 1999. An Enigmatic New Crocodile from the Upper Cretaceous of Madagascar. Spec Pap Palaeontol 60: 149-175.
BUFFETAUT E AND TAQUET P. 1977. The giant crocodilian Sarcosuchus in the early Cretaceous of Brazil and Niger. Palaeontology 20: 203-208.

CAMPOS DA AND CAMPOS DRB. 1976b. Apêndice II: Localidades fossilíferas da Folha Salvador SD. 24. In Pedreira AJCL et al. (Eds), Carta Geológica do Brasil ao Milionésimo, Folha Salvador - SD. 24. Departamento Nacional da Produção Mineral, Rio de Janeiro, Brasil, p. 91-104.

CAMPOS DRB AND CAMPOS DA. 1976a. Apêndice II: Localidades fossilíferas da Folha Aracaju - SC. 24. In: Bruni MAL et al. (Eds), Carta Geológica do Brasil ao Milionésimo, Folha Aracaju - SC. 24. Departamento Nacional da Produção Mineral, Rio de Janeiro, Brasil, p. 167-204.

COLBERT ED AND MOOK CC. 1951. The ancestral crocodilian Protosuchus. B Am Mus Nat Hist 97: 143-182.

COSTA IP, MILHOMEM PS, BUENO GV, SILVA HSRLS AND KOSIN MD. 2007. Sub-bacias de Tucano Sul e Central. B Geoci Petrobras 15: 433-443.

COTTS L, PINHEIRO EP, MARINHO TS, CARVALHO IS AND DARIO FD. 2017. Postcranial skeleton of Campinasuchus dinizi (Crocodyliformes, Baurusuchidae) from the Upper Cretaceous of Brazil, with comments on the ontogeny and ecomorphology of the species. Cretaceous Res 70: 163-188.

FIGUEIREDO RG AND KELLNER AWA. 2009. A new crocodylomorph specimen from the Araripe Basin (Crato Member, Santana Formation), northeastern Brazil. Paläontol Z 83: 323-331.

FREITAS MV. 2002. Charles Frederick Hartt, um naturalista no império de Pedro II. Belo Horizonte, UFMG/Humanitas, $282 \mathrm{p}$.

GAVA A, NASCIMENTO DA, VIDAL JLB, GHIGNONE JI, OLIVEIRA EP, FILHO ALS AND TEIXEIRA W. 1983. Geologia das Folhas SC.24/25 Aracaju/Recife. Rio de Janeiro, Projeto RadamBrasil, p. 27-376 (Levantamento de recursos naturais 30 ).

GODOY PL, BRONZATI M, ELTINK E, MARSOLA JCA, CIDADE GM, LANGER MC AND MONTEFELTRO FC. 2016. Postcranial anatomy of Pissarrachampsa sera (Crocodyliformes, Baurusuchidae) from the Late Cretaceous of Brazil: insights on lifestyle and phylogenetic significance. PeerJ 10.7717/peerj.2075.

GOMANI EM. 1997. A Crocodyliform from the Early Cretaceous Dinosaur Beds, Northern Malawi. J Vertebr Paleontol 17: 280-294.

HASTINGS AK, BLOCH JI AND JARAMILLO CA. 2014. A new blunt-snouted dyrosaurid, Anthracosuchus balrogus gen. et sp. nov. (Crocodylomorpha, Mesoeucrocodylia), from the Palaeocene of Colombia. Hist Biol 27: 998-1020. 
HILL RV. 2010. Osteoderms of Simosuchus clarki (Crocodyliformes: Notosuchia) from the Late Cretaceous of Madagascar. J Vertebr Paleontol 30: 154-176.

HUA S, BUFFETAUT E, LEGALL C AND ROGRON P. 2007. Oceanosuchus boecensis n. gen, n. sp., a marine pholidosaurid (Crocodylia, Mesosuchia) from the Lower Cenomanian of Normandy (western France). Bull Soc Séol Fr 6: 503-513.

IORI FV AND ARRUDA-CAMPOS AC. 2016. Os Crocodiliformes da Formação Marília (Bacia Bauru, Cretáceo Superior) na Região de Monte Alto, estado de São Paulo, Brasil. Rev Bras Paleontol 19: 537-546.

JOUVE S, IAROCHÈNE M, BOUYA B AND AMAGHZAZ M. 2006. A new species of Dyrosaurus (Crocodylomorpha, Dyrosauridae) from the early Eocene of Morocco: phylogenetic implications. Zool J Linn Soc-Lond 148: 603-656.

JOUVE S AND SCHWARZ D. 2004. Congosaurus bequaerti, a Paleocene Dyrosaurid (Crocodyliformes; Mesoeucrocodylia) from Landana (Angola). Bull Inst R Sc N B-S 74: 129-146.

KELLNER AWA. 1987. Ocorrência de um Novo Crocodiliano no Cretáceo Inferior da Bacia do Araripe, Nordeste do Brasil. An Acad Bras Cienc 59: 219-232.

LEARDI JM, POL D, NOVAS FE AND RIGLOS MS. 2015. The Postcranial Anatomy of Yacarerani boliviensis and the Phylogenetic Significance of the Notosuchian Postcranial Skeleton. J Vertebr Paleontol 35(6): e995187-2.

LECUONA A AND DESOJO JB. 2011. Hind limb osteology of Gracilisuchus stipanicicorum (Archosauria: Pseudosuchia). Earth Env Sci T R So 102: 105-128.

LIMA MIC, FONSÊCA EG, OLIVEIRA EP, GHIHNONE JI, ROCHA RM, CARMO UF, SILVA JMR AND SIGA O. 1981. Geologia da Folha SD.24 Salvador. Rio de Janeiro, Projeto RadamBrasil, p. 25-192 (Levantamento de recursos naturais 24).

MAISEY JG. 1991. Santana Fossils an illustrated atlas. Neptune, T.F.H, 459 p.

MAISEY JG. 2000. Continental break up and the distribution of fishes of Western Gondwana during the Early Cretaceous. Cretaceous Res 21: 281-314.

MARINHO TS AND CARVALHO IS. 2009. An armadillolike sphagesaurid crocodyliform from the Late Cretaceous of Brazil. J S Am Earth Sci 27: 36-41.

MARINHO TS, RIBEIRO LCB AND CARVALHO IS. 2006. Morfologia de Osteodermos de Crocodilomorfos do Sítio Paleontológico de Peirópolis (Bacia Bauru, Cretáceo Superior). Anuário IGeo 29: 44-53.

MARSH OC. 1869. Notice of some new reptilian remains from the Cretaceous of Brazil. Am J Sci Arts 47: 1-3.

MARTIN JE, RASLAN-LOUBATIÉ J AND MAZIN JM. 2016. Cranial anatomy of Pholidosaurus purbeckensis from the Lower Cretaceous of France and its bearing on pholidosaurid affinities. Cretaceous Res 66: 43-59.

MAWSON J AND WOODWARD AS. 1907. On the Cretaceous formation of Bahia (Brazil), and on vertebrate fossils collected therein. Q J Geol Soc London 63: 128139.

MEERS MB. 2003. Crocodylian forelimb musculature and its relevance to Archosauria. Anat Rec Part A 274A: 891-916.

MELO JUNIOR JL AND OLIVEIRA PE. 1939. Novas localidades fossiliferas do Nordeste da Baía. Bol Divisão Geol Mineral, Rio de Janeiro (103): 85. est, 2 mapas.

MILANI EJ AND DAVISON I. 1988. Basement control and transfer tectonics in the Recôncavo - Tucano - Jatobá rift, Northeast Brazil. Tectonophysics 154: 41-70.

MOOK CC. 1921. Notes on the postcranial skeleton in the Crocodilia. B Am Mus Nat Hist 44: 67-100.

NASCIMENTO PM AND ZAHER H. 2010. A new species of Baurusuchus (Crocodyliformes, Mesoeucrocodylia) from the upper Cretaceous of Brazil, with the first complete postcranial skeleton described for the family Baurusuchidae. Pap Avulsos Zool 50: 323-361.

NASH DS. 1975. The morphology and relationships of a Crocodilian, Orthosuchus stormbergi, from the Upper Triassic of Lesotho. Ann S Af Mus 67: 227-329.

NOBRE PH. 2004. Morfologia pós-craniana de Candidodon itapecuruense (Crocodylomorpha, Mesoeucrocodylia), do Cretáceo do Brasil. Rev Bras Paleontol 7: 87-92.

NOBRE PH AND CARVALHO IS. 2006. Adamantinasuchus navae: A new Gondwanan Crocodylomorpha (Mesoeucrocodylia) from the Late Cretaceous of Brazil. Gondwana Res 10: 370-378.

POL D. 2005. Postcranial remains of Notosuchus terrestris (Archosauria: Crocodyliformes) from the upper Cretaceous of Patagonia, Argentina. Ameghiniana 42: 21-38.

POL D, LEARDI JM, LECUONA A AND KRAUSE M. 2012. Postcranial anatomy of Sebecus icaeorhinus (Crocodyliformes, Sebecidae) from the Eocene of Patagonia. J Vertebr Paleontol 32: 328-354.

PRICE LI. 1945. A new reptile from the Cretaceous of Brazil. Divisão de Geologia e Paleontologia, Notas Preliminares e Estudos 25: 1-8.

PRICE LI. 1955. Novos Crocodilídeos dos arenitos da Série Baurú, Cretáceo do Estado de Minas Gerais. An Acad Bras Cienc 27: 487-498.

RIFF D AND KELLNER AWA. 2011. Baurusuchid crocodyliforms as theropod mimics: clues from the skull and appendicular morphology of Stratiotosuchus maxhechti (Upper Cretaceous of Brazil). Zool J Linn SocLond 163: S37-S56.

RIFF D, SOUZA RG, CIDADE GM, MARTINELLI AG AND SOUZA-FILHO JP. 2012. Crocodilomorfos: a maior diversidade de répteis fósseis do Brasil. Terræ 9: 12-40. 
ROMER AS. 1956. Osteology of the Reptiles. Chicago: The University of Chicago Press, 772 p.

ROMER AS. 1972. The Chañares (Argentina) Triassic Reptile Fauna. XIII. An Early Ornithosuchid Pseudosuchian Gracilisuchus stipanicicorum gen. et sp. nov. Breviora 389: 388-390.

SALISBURY SW AND FREY E. 2001. A biomechanical transformation model for the evolution of semi-spheroidal articulations between adjoining vertebral bodies in crocodilians. In: Grigg GC et al. (Eds), Crocodilian biology and evolution, Surrey Beaty \& Sons, Chipping Norton, p. 85-134.

SALISBURY SW, FREY E, MARTILL DM AND BUCHY MC. 2003. A new crocodilian from the Lower Cretaceous Crato Formation of north-eastern Brazil. Paleontographica Abt A 270: 3-47.

SERENO PC AND LARSSON HCE. 2009. Cretaceous Crocodyliforms from the Sahara. ZooKeys 28: 1-143.

SERENO PC, LARSSON HCE, SIDOR CA AND GADO B. 2001. The Giant Crocodyliform Sarcosuchus from the Cretaceous of Africa. Science 294: 1516-1519.

SCHWARZ D, FREY E AND MARTIN T. 2006. The postcranial skeleton of the Hyposaurinae (Dyrosauridae; Crocodyliformes). Paleontology 49: 695-718.

SCHWARZ D AND SALISBURY SW. 2005. A new species of Theriosuchus (Atoposauridae, Crocodylomorpha) from the Late Jurassic (Kimmeridgian) of Guimarota, Portugal. Geobios 38: 779-802.

SCHWIMMER DR. 2002. King of the Crocodylians: the paleobiology of Deinosuchus. Bloomington: Indiana University Press, $220 \mathrm{p}$.

SERTICH JWS AND GROENKE JR. 2010. Appendicular skeleton of Simosuchus clarki (Crocodyliformes:
Notosuchia) from the Late Cretaceous of Madagascar. J Vertebr Paleontol 30: 122-153.

SILVA OB, CAIXETA JM, MILHOMEM PS AND KOSIN MD. 2007. Bacia do Recôncavo. Bol Geocienc Petrobras 15: 423-431.

SOUZA RG, RIFF D AND KELLNER AWA. 2015. Taxonomic revision of Thoracosaurus bahiensis Marsh, 1869, a supposed Gavialoidea (Reptilia, Crocodylia) from cretaceous deposits of the Recôncavo Basin, Brazil. Rev Bras Paleontol 18: 565-568.

TAVARES SAS, RICARDI-BRANCO F AND CARVALHO IS. 2015. Osteoderms of Montealtosuchus arrudacamposi (Crocodyliformes, Peirosauridae) from the TuronianSantonian (Upper Cretaceous) of Bauru Basin, Brazil. Cretaceous Res 56: 651-661.

TURNER AH. 2006. Osteology and phylogeny of a new species of Araripesuchus (Crocodyliformes: Mesoeucrocodylia) from the Late Cretaceous of Madagascar. Hist Biol 18: 255-369.

VASCONSELLOS FM, ARRUDA JT, ROCHA-BARBOSA O AND CARVALHO IS. 2004. Falanges ungueais de crocodilomorfos da Bacia Bauru (Cretáceo Superior, Brasil). Anuário IGeo 27: 53-63.

WU XC, RUSSEL AP AND CUMBAA SL. 2001. Terminonaris (Archosauria: Crocodyliformes): new material from Saskatchewan, Canada, and comments on its phylogenetic relationships. J Vertebr Paleontol 21: 492-514.

YOUNG MT, HASTINGS AK, ALLAIN R AND SMITH TJ. 2016. Revision of the enigmatic crocodyliform Elosuchus felixi de Lapparent de Broin, 2002 from the Lower-Upper Cretaceous boundary of Niger: potential evidence for an early origin of the clade Dyrosauridae. Zool J Linn SocLond 10.1111/zoj.12452. 